\title{
GLYCEROL KINASE AND DIHYDROXYACETONE KINASE IN RAT BRAIN
}

\author{
B. T. JENKINS and A. K. HAJRA \\ Neuroscience Laboratory, Mental Health Research Institute and \\ the Department of Biological Chemistry, University of Michigan, \\ Ann Arbor, MI 48104, U.S.A.
}

(Received 24 March 1975. Accepted 30 July 1975)

\begin{abstract}
The enzymatic phosphorylation of glycerol and dihydroxyacetone by ATP to sn-glycerol-3phosphate and dihydroxyacetone phosphate respectively in various subcellular fractions of rat brain was studied. A sensitive radiochemical assay was used where the labelled phosphorylated products were separated from the radioactive substrates by high voltage paper electrophoresis and the radioactivity in these compounds determined. Using this assay the glycerol kinase (EC 2.7.1.30) activity was found to be associated with the mitochondrial fraction of the brain. Under optimum conditions $2.45 \mathrm{nmol}$ of glycerol was phosphorylated/min per $\mathrm{mg}$ of protein. The $K_{m}$ for glycerol was $70 \mu \mathrm{m}$ at $\mathrm{pH}$ 7. This mitochondrial enzyme, like other glycerol kinases from different sources, also phosphorylated dihydroxyacetone. Under optimum conditions $1.7 \mathrm{nmol}$ of dibydroxyacetone phosphate was formed/min per $\mathrm{mg}$ of mitochondrial protein. The $K_{m}$ for dihydroxyacetone was $0.6 \mathrm{~mm}$.

Glycerol kinase activity was also present in the cytoplasm of brain. However, the specific activity of this enzyme in cytosol is about $15 \%$ of the mitochondrial glycerol kinase. Compared to glycerol, dihydroxyacetone was phosphorylated by ATP in cytoplasm at a much higher rate. The $\mathrm{pH}$ optimum for this soluble dihydroxyacetone kinase was much lower ( $\mathrm{pH} \mathrm{6.5)} \mathrm{than} \mathrm{that} \mathrm{of} \mathrm{the} \mathrm{soluble} \mathrm{or} \mathrm{mitochon-}$ drial glycerol kinase $(\mathrm{pH} \mathrm{100)}$. Using ammonium sulfate, brain cytoplasm was fractionated to yield a fraction in which the dihydroxyacetone kinase was enriched 2-3 fold with no glycerol kinase activity. Under optimum conditions $1.0 \mathrm{nmol}$ of dihydroxyacetone was phosphorylated/min per $\mathrm{mg}$ protein. The $K_{m}$ for dihydroxyacetone was $60 \mu \mathrm{M}$. This cytosol fraction was also found to phosphorylate D-glyecraldehyde and L-glyceraldehyde at a rate of $30-40 \%$ to that of the dihydroxyacetone phosphorylation. The properties and the possible metabolic role of these enzymes in brain are discussed.
\end{abstract}

GLYCEROL kinase (ATP: glycerol-3-phosphotransferase EC 2.7.1.30) catalyzes the phosphorylation of glycerol by ATP to sn-glycerol-3-phosphate (G-3-P). This enzyme was discovered by KALCKAR (1939) in kidney. The properties of the enzyme were first described in detail by BUBLITZ \& KENNEDY (1954); WIELAND \& SUYTER (1957). Using an enzymatic assay, WIELAND \& SUYTER (1957) concluded that this kinase activity is present only in liver and kidney but not in other mammalian organs. However, later workers using more sensitive assays showed the presence of this enzyme in a wide variety of tissues (for a review see Thorner \& Paulus, 1973). To date glycerol kinase has not been described in the brain, although there is indirect evidence to suggest its presence in that organ. A number of workers showed that when radioactive glycerol was injected intracranially into rats it was incorporated into the brain glycerolipids (HoK IN \& HoKIN, 1958; LAPETINA et al., 1969; BENJAMINS \& MCKhaNN, 1973; O’Brien \& GeIsON, 1974). This suggests that glycerol is phosphorylated in brain to G-3-P and subsequently acylated and converted to different lipids (KENNEDY, 1962).

Abbreviations used: G-3-P, sn-glycerol-3-phosphate; DHAP, Dihydroxyacetone phosphate.
Glycerol kinase is also known to catalyze the phosphorylation of dihydroxyacetone and L-glyceraldehyde with ATP to form dihydroxyacetone phosphate (DHAP) and L-glyceraldehyde-3-phosphate, respectively (BUBLITZ \& KENNEDY, 1954; WIELAND \& SUYTER, 1957). During the course of the investigations on the pathways for the metabolism of glycero-lipids in brain, we studied the glycerol kinase and dihydroxyacetone kinase activity in different subcellular fractions of brain by using a sensitive radiochemical assay. The results indicated that glycerol kinase activity is confined primarily to the mitochondrial fraction. Less activity was found in the $100,000 \mathrm{~g}$ supernatant fraction; however the conversion of dihydroxyacetone to DHAP was noted to be significantly higher in this fraction than could be accounted for by the glycerol kinase activity alone. Further studies showed the presence of another enzyme in the cytosol which phosphorylates dihydroxyacetone to DHAP by ATP. The properties of these enzymes are described in this paper.

\section{MATERIALS AND METHODS}

Materials

$\left[1-{ }^{14} \mathrm{C}\right]$ glycerol and ${ }^{32} \mathrm{P}_{i}$ were obtained from New England Nuclear (Cambridge, Mass.). $\left[\mathrm{U}^{14} \mathrm{C}\right]$ dihydroxyacetone was obtained from ICN (Irvine, Calif.). $\mathrm{NAD}^{+}$, 
NADH, dihydroxyacetone, glycerol kinase, triose phosphate isomerase and G-3-P dehydrogenase were from Boehringer Mannheim Corp. (New York, N.Y.) and from Sigma (St. Louis, Mo). $\left[\gamma^{32} \mathrm{P}\right]$ ATP was prepared from ${ }^{32} \mathrm{P}_{i}$ and ATP by an enzymatic exchange reaction (GLYNN \& CHAppl, 1964). 1-Chloro, 3-hydroxyacetone phosphate (chloroacetol phosphate) was a kind gift of Dr. F. Hartman (Oak Ridge, Tenn.). D-Glyceraldehyde and L-glyceraldehyde were obtained from Fluka, A. G. (Basel, Switzerland). Other materials were the same as previously described (LABFLle \& HaJRA 1972a,b).

\section{Purification of substrates}

The $\left[1-{ }^{14} \mathrm{C}\right]$ glycerol and $\left[\mathrm{U}^{1}{ }^{14} \mathrm{C}\right]$ dihydroxyacetone were assayed for purity by ascending paper chromatography with a solvent system of ethyl acetate-pyridine-water (120:50:40). Dihydroxyacetone $\left(R_{f}=0.74\right)$, glycerol $\left(R_{f}=0.57\right)$ and DL-glyceraldehyde $\left(R_{f}=0.34\right)$ are separable from each other in this system. The $\left[1-{ }^{14} \mathrm{C}\right]$ glycerol showed contamination with compounds which migrated with dihydroxyacetone $(3 \%)$ and glyceraldehyde $(1 \%)$. No impurities, especially in the glycerol and glyceraldehyde regions, were detected in the $\left[\mathrm{U}-{ }^{14} \mathrm{C}\right]$ dihydroxyacetone.

The impurities in glycerol could be removed by reduction with $\mathrm{NaBH}_{4}$. The $\left[1-{ }^{14} \mathrm{C}\right]$ glycerol $(100 \mu \mathrm{Ci} / 0.8$ $\mu \mathrm{mol} / 0.1 \mathrm{ml})$ in water was treated with $0.05 \mathrm{ml}$ of an aqueous solution of $\mathrm{NaBH}_{4}(0.1 \mathrm{~m})$ for $30 \mathrm{~min}$ at room temperature. The excess borohydride was decomposed by $5 \mu \mathrm{l}$ of $6 \mathrm{~N}-\mathrm{HCl}$ and the $\mathrm{pH}$ was then adjusted to $7 \cdot 0$. When examined by paper chromatography, the $\mathrm{NaBH}_{4}$-treated glycerol showed a single radioactive spot migrating with glycerol, and negligible radioactivity in the dihydroxyacetone or glyceraldehyde regions. This reduced $\left[1-{ }^{14} \mathrm{C}\right] \mathrm{gly}-$ cerol contained a small amount of borate, however this had no effect on the enzyme activity and the labelled glycerol was used directly for the assays.

\section{Subcellular fractionation of the brain}

Fifteen-day old male rats were sacrificed by $\mathrm{CO}_{2}$ inhalation and the brains were quickly removed. Fractionation of the rat brains into crude mitochondria, microsomes and a $100,000 \mathrm{~g}$ supernatant was accomplished by differential centrifugation of the $10 \%$ homogenate in $0.25 \mathrm{~m}$-sucrose containing EDTA (1 mM) (Brody \& BAIN, 1952). The crude mitochondrial fraction was further resolved into mitochondrial, synaptosomal, and myelin fractions by a discontinuous density gradient centrifugation (GRAY \& WHITTAKER, 1962; SCHACHT \& AGRANOFF, 1972). The mitochondrial, synaptosomal and microsomal fractions were washed twice with $0.25 \mathrm{M}$-sucrose and resuspended in $0.25 \mathrm{M}$-sucrose to give a concentration of 2 to $8 \mathrm{mg}$ protein per $\mathrm{ml}$. These fractions and the $100,000 \mathrm{~g}$ supernatant were kept frozen at $-20^{\circ} \mathrm{C}$ in small batches and thawed immediately preceding their use.

The protein in the $100,000 \mathrm{~g}$ supernatant was first concentrated by precipitation with ammonium sulfate and the concentrated supernatant $(10 \mathrm{mg}$ protein $/ \mathrm{ml}$ ) was used for the ammonium sulphate fractionation. The cytosol was dialyzed overnight against 2 litres of $10 \mathrm{~mm}$-citrate-phosphate buffer ( $\mathrm{pH} 6.1)$ to remove the sucrose and then brought to $90 \%$ saturation with powdered ammonium sulphate. The precipitate was collected by centrifugation $(13,000 \mathrm{~g}, 20 \mathrm{~min})$ and then resuspended in a minimum vol of water and again dialyzed against 2 litres of $1 \mathrm{~mm}$-citratephosphate buffer ( $\mathrm{pH}$ 6.1). The concentrated supernatant was then centrifuged once again to remove insoluble pro- tein and was then used for further fractionation with ammonium sulphate. An $\mathrm{S}_{1}$ fraction was prepared containing protein which precipitated at a level of $50 \%$ saturation with ammonium sulphate. The dialyzed $S_{1}$ fraction $(10 \mathrm{mg}$ protein $/ \mathrm{ml}$ ) was treated with ammonium sulphate to $20 \%$ saturation and the precipitate was removed. The supernatant $\left(\mathbf{S}_{2}\right)$, which contained most of the dihydroxyacetone kinase, was dialyzed to remove the salt and kept frozen at $-20^{\circ} \mathrm{C}$.

\section{Assay of the kinases}

The enzymes were assayed radiometrically using labelled glycerol and dihydroxyacetone. The assay mixture contained ATP (5 mM), $\mathrm{MgCl}_{2}$ (5 mM), 2-mercaptoethanol ( $5 \mathrm{~mm}$ ), NaF (20 mM), buffer (various types and $\mathrm{pH}, 60 \mathrm{~mm}$ ), labelled glycerol or dihydroxyacetone $(0.2 \mathrm{~mm})$, and enzyme from different subcellular fractions $(0.01-0.3 \mathrm{mg}$ protein) in a total vol of $0.1 \mathrm{ml}$. On various occasions, when the enzymes from the $100,000 \mathrm{~g}$ supernatant were used, 1-chloro, 3-hydroxyacetone phosphate $(0.025 \mathrm{~mm})$ was also included in the reaction mixture to inhibit the triose-P isomerase (HAR TMAN, 1970). Because the brain cytosol contains triose-P isomerase and aldolase, a part of the product formed from dihydroxyacetone (i.e. DHAP) is converted to D-fructose 1.6-diphosphate. Addition of the chloroacetol phosphate prevented the conversion of DHAP to fructose diphosphate. The concentrations of the reagents varied slightly from one experiment to another and are included for the appropriate cases. The reaction mixture was incubated for $15-30 \mathrm{~min}$ at $37^{\circ} \mathrm{C}$ in a shaking water bath, and the reaction was stopped by placing the reaction tubes on ice and immediately adding $30 \mu \mathrm{l}$ of $0.3 \mathrm{M}$-oxalic acid to each incubation mixture. Addition of oxalic acid decreased the $\mathrm{pH}$ to 1.5 thereby stopping the enzymatic reaction and also adjusting the $\mathrm{pH}$ of the reaction mixture to that used for electrophoresis. A $20 \mu \mathrm{l}$ aliquot was removed from each reaction vessel and spotted as a $1-1.5 \mathrm{~cm}$ band on Whatman No. 1 paper for electrophoresis at pH 1-5 (0.08 $\mathrm{M}$-oxalate buffer), at $4000 \mathrm{~V}$ for $30 \mathrm{~min}$ (HAJRA \& AGRANOFF, 1968). In this electrophoretic system, DHAP. G-3-P and DL-glyceraldehyde-3-P migrate at different rates and are separable from cach other. In a typical run (Fig. 1) DHAP migrated $21 \mathrm{~cm}$ from the origin compared to $18 \mathrm{~cm}$ for $\mathrm{G}-3-P$ and $17 \mathrm{~cm}$ for DL-glyceraldehyde-3-P. The finished electrophoretograms were radioautographed and the zones of interest cut out and counted directly in a liquid scintillation counter (Beckman LS-133) by immersing the paper in $10 \mathrm{ml}$ of scintillation fluid in vials. The scintillation fluid contained toluene $(950 \mathrm{ml})$, ethanol $(50 \mathrm{ml}), 2,5$-diphenyl oxazole (PPO) $(5 \mathrm{~g})$ and 7,4-bis[2,4 methyl-5-phenyloxazolyl] benzene (dimethyl POPOP) $(0 \cdot 2 \mathrm{~g})$. Counting efficiency of the vials containing the paper was $75 \%$ for ${ }^{14} \mathrm{C}$ and $90 \%$ for ${ }^{32} \mathrm{P}$.

A different procedure was used when $\left[\gamma^{-32} \mathrm{P}\right] \mathrm{ATP}$ was used as the labelled substrate. The incubation mixture was the same as described above except that $\left[\gamma^{32} \mathrm{P}\right]$ ATP $(0.2 \mathrm{~mm})$ was incubated with non-radioactive glycerol or dihydroxyacetone or $\mathrm{D}$ - or L-glyceraldehyde $(0.4 \mathrm{mM})$. Because ATP migrated very close to G-3-P $\left(R_{G-3-P}=0.95\right)$ and glyceraldehyde-3-phosphate in the electrophoretic system, it was necessary to hydrolyze radioactive ATP to ${ }^{32} \mathbf{P}_{i}$ before electrophoresis. When DHAP or glyceraldehyde-3-P were the products, they were first reduced to the acid stable G-3-P before the hydrolysis of ATP as described below. The enzymatic reaction was stopped by adding $10 \mu \mathrm{l}$ of $0.05 \mathrm{M}-\mathrm{NaBH}_{4}$ to the incubation mixture and the solution 
was kept at $0^{\circ} \mathrm{C}$. After $10 \mathrm{~min}$ another $10 \mu \mathrm{l}$ of $\mathrm{NaBH}_{4}$ $(0.05 \mathrm{M})$ solution was added and the reaction was allowed to continue for $10 \mathrm{~min}$ more prior to the addition of $1.0 \mathrm{ml}$ of $1.0 \mathrm{~N}-\mathrm{HCl}$ to each tube. The tubes were heated at $100^{\circ} \mathrm{C}$ for $15 \mathrm{~min}$ to hydrolyze the ATP and then evaporated to dryness. The residue was dissolved in a small volume of water and the solution was used for the clectrophoretic separation of labelled G-3-P and ${ }^{32} \mathrm{P}_{i}$ as described before.

Protein was determined by the method of LowRY et al. (1951). Other methods were the same as described previously (LABELle \& HAJRA, 1972a,b).

\section{RESULTS}

Enzymatic phosphorylation of glycerol and dihydroxyacetone in brain subcellular fractions

Both $\left[1-{ }^{14} \mathrm{C}\right]$ glycerol and $\left[\mathrm{U}-{ }^{14} \mathrm{C}\right]$ dihydroxyacetone were shown to be phosphorylated in whole brain homogenate to form radioactive G-3-P and DHAP respectively. Under the assay conditions described in Table 1 , about $3.1 \mu \mathrm{mol}$ of glycerol and $1.7 \mu \mathrm{mol}$ of dihydroxyacetone were phosphorylated $/ \mathrm{h}$ per $\mathrm{g}$ of brain. Table 1 shows the distribution of enzyme activity for the phosphorylation of glycerol and dihydroxyacetone in various subcellular fractions of brain. Glycerol kinase activity was primarily found in the mitochondrial and the $100,000 \mathrm{~g}$ supernatant fractions. Very little enzymatic activity was found in other fractions. Dihydroxyacetone kinase activity was also found in the fractions showing activity for the phosphorylation of glycerol. However, whereas the rate of dihydroxyacetone phosphorylation is lower in mitochondria than the rate of glycerol phosphorylation, in the $100,000 \mathrm{~g}$ supernatant the rate is almost 4 times higher for dihydroxyacetone than for glycerol.

Table 2 shows the requirements for different cofactors of the mitochondrial glycerol kinase and the soluble dihydroxyacetone kinase. It was seen that ATP is absolutely required for both kinases. Magnesium was essential for dihydroxyacetone kinase activity, but the mitochondrial glycerol kinase was fairly active in the absence of $\mathrm{Mg}^{2+}$. This was probably due to the presence of endogenous $\mathrm{Mg}^{2+}$ because the addition of EDTA completely inhibited the glycerokinase activity (Table 2). Both kinases were found to be stimulated by mercaptoethanol (Table 2). NaF stimulated the mitochondrial glycerol kinase activity, probably by inhibiting the ATPase and phosphatase activity. It had no effect on the soluble dihydroxyacetone kinase activity.

\section{Characterization of the products}

The properties of the labelled products formed from $\left[1-{ }^{14} \mathrm{C}\right]$ glycerol and $\left[\mathrm{U}-{ }^{14} \mathrm{C}\right]$ dihydroxyacetone in brain mitochondria and cytosol resemble those of G-3-P and DHAP respectively. For example, the product formed from labelled glycerol migrated with standard G-3-P on high voltage paper electrophoresis at $\mathrm{pH} 1.5$ (Fig. 1), and also at $\mathrm{pH} 4.3$ and $\mathrm{pH}$. The labelled product was found to be stable to hydrolysis by acid $\left(1 \mathrm{~N}-\mathrm{HCl}, 100^{\circ} \mathrm{C}, 10 \mathrm{~min}\right)$ and alkali $\left(1 \mathrm{~N}-\mathrm{KOH}, 10 \mathrm{~min}, 40^{\circ} \mathrm{C}\right.$. When unlabelled glycerol, $\left[\gamma^{32} \mathrm{P}\right] \mathrm{ATP}$ and other cofactors were used, the ${ }^{32} \mathrm{P}$ labelled product had the same migration rate on high voltage electrophoresis at $\mathrm{pH} 4.3$ as the ${ }^{14} \mathrm{C}$-labelled product described above.

The labelled product formed from ${ }^{14} \mathrm{C}$-labelled glycerol and ATP in the brain mitochondrial fraction was found to be converted to labelled phosphatidic acid after incubation with acyl CoA and brain microsomes. The phosphatidic acid was characterized by solvent extraction followed by TLC (LABELLF \& HAJRA 1972a).

Similarly, the product formed from labelled dihydroxyacetone was found to migrate with DHAP at different $\mathrm{pH}$ on high voltage paper electrophoresis (see Fig. 1). The same product was formed when unlabelled dihydroxyacetone and $\left[\gamma_{-}{ }^{32} \mathrm{P}\right] \mathrm{ATP}$ were used. The product formed from dihydroxyacetone, like DHAP (MeyerhoF \& LohmanN, 1934; Hajra \&

TABLE 1. ENTYMATIC PHOSPHORYLATION OF DIHYDROXYACFTONE AND GLYCEROL IN VARIOUS SUBCELLULAR FRACTIONS OF BRAIN

\begin{tabular}{|c|c|c|c|c|c|}
\hline \multirow[b]{2}{*}{$\begin{array}{l}\text { Subcellular } \\
\text { fractions }\end{array}$} & \multirow[b]{2}{*}{$\begin{array}{c}\text { Protein } \\
(\mu \mathrm{g})\end{array}$} & \multicolumn{4}{|c|}{ Product } \\
\hline & & (c.p.m.) & $\begin{array}{l}\text { [G-3-P from } \\
{ }^{4} \text { C]glycerol } \\
\text { (nmol/mg protein) }\end{array}$ & $\underset{\text { (c.p.m.) }}{\left[\mathrm{U}^{1}{ }^{1 / 4}\right.}$ & $\begin{array}{l}\text { DHAP from } \\
\text { dihydroxyacetone } \\
\text { (nmol/mg protein) }\end{array}$ \\
\hline Mitochondria & 70 & 2770 & $11 \cdot 0$ & 1890 & $5 \cdot 1$ \\
\hline Mitochondria* & 70 & 15 & - & 20 & - \\
\hline Synaptosomes & 130 & 320 & $0 \cdot 7$ & 360 & 0.5 \\
\hline Microsomes & 85 & 45 & $0 \cdot 1$ & 300 & 0.6 \\
\hline $100,000 \mathrm{~g}$ supernatant & 55 & 370 & 1.9 & 2190 & $7 \cdot 6$ \\
\hline $100,000 \mathrm{~g}$ supernatant* & 55 & 0 & - & 0 & - \\
\hline
\end{tabular}

The incubation mixture contained citrate-phosphate buffer $(60 \mathrm{mM}, \mathrm{pH} 7 \cdot 1)$, ATP ( $5 \mathrm{~mm}), \mathrm{MgCl}_{2}$ ( 5 mM), 2-mercaptoethanol $(5 \mathrm{~mm})$, NaF $(20 \mathrm{~mm})$, either $\left[1{ }^{14} \mathrm{C}\right.$ ]glycerol $\left(0.2 \mathrm{~mm}, 4.68 \times 10^{5}\right.$ c.p.m.) or [U-14 C]dihydroxyacetone $(0.2 \mathrm{~mm}$, $6.9 \times 10^{5}$ c.p.m.) and different brain subcellular fractions as noted below in a total vol of $0.1 \mathrm{ml}$. The mixtures were incubated for $15 \mathrm{~min}$ at $37^{\circ} \mathrm{C}$ and the reaction was stopped by adding $30 \mu \mathrm{l}$ of $0.3 \mathrm{M}$-oxalic acid to each tube. A $20 \mu \mathrm{l}$ aliquot from each tube was used for separating the products from the substrate by high voltage paper electrophoresis as described in the text. The radioactivity reported here is the count recovered in the DHAP or G-3-P spots on the electrophoretogram which is approx $15 \%$ of the total product formed in the incubation mixture.

* These enzyme fractions were heated at $100^{\circ} \mathrm{C}$ for 10 min before use. 
TABLE 2. RFQUIRFMENTS FOR THE ENZYMATIC PHOSPHORYLATION OF GLYCEROL ANID DIHYDROXYACETONE IN BRAIN

\begin{tabular}{lcc}
\multicolumn{1}{c}{ System } & $\begin{array}{c}\text { Expt. 1 } \\
{\left[1-{ }^{14} \mathrm{C}\right] \mathrm{G}-3-P \text { formed }} \\
\text { nmol }\end{array}$ & $\begin{array}{c}\text { Expt. 2 } \\
{\left[\mathrm{U}-{ }^{14} \mathrm{C}\right] \text { DHAP formed }} \\
\text { nmol }\end{array}$ \\
\hline Whole systcm & 0.71 & 1.48 \\
Wholc $-\mathrm{ATP}$ & 0.01 & 0.02 \\
Whole $-\mathrm{MgCl}_{2}$ & 0.46 & 0.06 \\
Whole $-\mathrm{MgCl}_{2}+$ EDTA $(2.5 \mathrm{mM})$ & 0.09 & 0.02 \\
Whole - mercaptocthanol & 0.65 & 1.01 \\
Wholc $-\mathrm{NaF}$ & 0.55 & 1.49 \\
Whole system (boiled) & 0.00 & 0.02 \\
\hline
\end{tabular}

The whole incubation mixture is the same as described under Table 1. In Experiment 1 the phosphorylation of $\left[11^{14} \mathrm{C}\right]$ glycerol $\left(0.2 \mathrm{~mm}, 4.6 \times 10^{5} \mathrm{c} . \mathrm{p} . \mathrm{m}\right.$.) by brain mitochondria $\left(60 \mu \mathrm{g}\right.$ protein) is studied. In Experiment 2 the phosphorylation of $\left[\mathrm{U}-{ }^{14} \mathrm{C}\right]$ dihydroxyacetone $\left(0.2 \mathrm{mM}, 5.98 \times 10^{5} \mathrm{c} . \mathrm{p} . \mathrm{m}\right.$.) with brain cytosol ammonium sulfate $(20-50 \%$ saturation, see later in the text) fraction (110 $\mu \mathrm{g}$ protein) to labelled DHAP at pH 6.1 (Citrate-phosphate buffers) was studied. The incubation period was $30 \mathrm{~min}$.

* These enzyme fractions were heated at $100^{\circ} \mathrm{C}$ for $10 \mathrm{~min}$ before use.

AGRANOFF, 1968), was found to be extremely labile to alkali. After incubation of $\left[\mathrm{U}-{ }^{14} \mathrm{C}\right]$ dihydroxyacetone with ATP and other cofactors in liver mitochondrial or supernatant fractions, aliquots of the mixture were treated with $\mathrm{NaOH}(\mathrm{pH} 12)$ at $37^{\circ} \mathrm{C}$ for $10 \mathrm{~min}$. The resulting mixture on high voltage electrophoresis showed no radioactive band corresponding to DHAP when compared to the sample not treated with alkali. Reduction of the reaction product (from $\left[{ }^{14} \mathrm{C}\right.$ ]dihydroxyacetone) with $\mathrm{NaBH}_{4}$ yielded a labelled product which migrated with G-3-P (Fig. 1). This reduced product was found to be stable to acid $(1 \mathrm{~N}-\mathrm{HCl}$, $\left.100^{\circ} \mathrm{C}, 10 \mathrm{~min}\right)$ and alkaline hydrolysis $(0.05 \mathrm{~N}-\mathrm{NaOH}$, $15 \mathrm{~min}$ at $25^{\circ} \mathrm{C}$ ). The product formed from labelled dihydroxyacetone in the $100,000 \mathrm{~g}$ supernatant fraction was also reduced enzymatically to G-3-P by adding NADH and glycerol-3-phosphate dehydrogenase to the reaction mixture. Finally, the ${ }^{14} \mathrm{C}$-labelled product was shown to be converted to labelled acyl DHAP after enzymatic acylation in brain microsomes with acyl COA as shown by TLC (LABELLE \& HAJRA, 1972a). These results confirmed the identity of the labelled product formed from labelled dihydroxyacetone and ATP as DHAP.

\section{Properties of the mitochondrial enzyme}

The mitochondrial fraction phosphorylates both dihydroxyacetone and glycerol to DHAP and G-3-P respectively. For both these substrates the enzymatic phosphorylation was found to have activity over a broad $\mathrm{pH}$ range between $\mathrm{pH} 7$ and $\mathrm{pH} 11$ (Fig. 2). The abnormal shape of these curves is not due to any nonencymatic reaction because the controls containing heated enzyme or no enzyme did not show any glycerol phosphorylation. It is of interest to note that the general shape of these curves is in agreement with those of glycerol kinases from other tissue sources (BubLITZ \& KenNedy, 1954; Haessler \& Isselbacher, 1963; HaYashi \& LIN, 1963). The pH optimum for dihydroxyacetone kinase was 10.0 and for the glycerol kinase $10-5$ (Fig. 2). There was a sharp drop of dihyd- roxyacetone kinase activity beyond $\mathrm{pH} 100$, probably due to the instability of DHAP at high $\mathrm{pH}$. The enzyme activities with both substrates were found to be linear with time to an incubation period of $10 \mathrm{~min}$ (Fig. 3) and also linear with increasing protein concentration up to $0-2 \mathrm{mg}$ protein (Fig. 3). The effect of increasing the substrate concentration on the enzyme activity is shown in Fig. $4 \mathrm{~A}$ and $4 \mathrm{~B}$. The rate of reaction with increasing concentration of dihydroxyacetone appears to be only of first order kinetics (Fig. 4B) because the concentration of the substrate used was below the $K_{m}{ }^{\cdot}$ However, the enzymatic reaction followed the Michaelis-Menten Kinetics as shown by the double reciprocal plot (Fig. 4B). The $K_{m}$ for dihydroxyacetone phosphorylation was $0.6 \mathrm{~mm}$. The $K_{m}$ for glycerol phosphorylation was $70 \mu \mathrm{m}$. The corresponding $V_{\mathrm{max}}$ values were $1.0 \mathrm{nmol} /$ min per mg protein for the formation of DHAP and

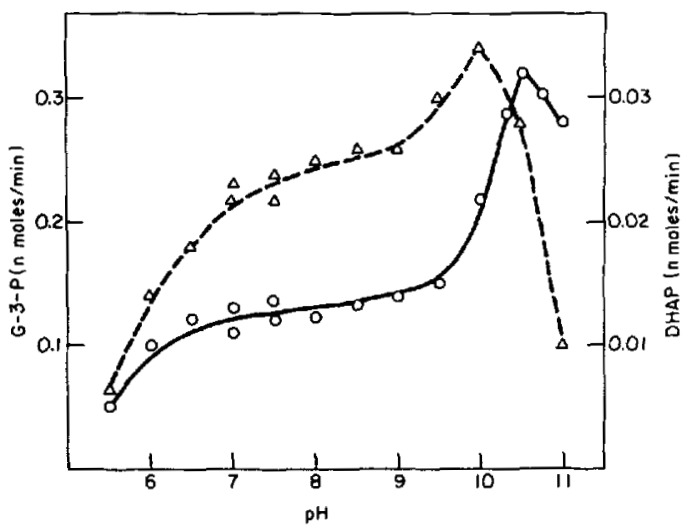

FIG. 2. Rates of glycerol phosphorylation and dihydroxyacetone phosphorylation in mitochondria as a function of $\mathrm{pH}$. The incubation mixtures and assay conditions were the same as described in Table 1 except the $\mathrm{pH}$ and composition of the buffers varied. The buffers $(60 \mathrm{~mm})$ used in the incubation mixtures were phosphate $(\mathrm{pH} 5 \cdot 5-7 \cdot 5)$, triethanolamine $-\mathrm{HCl}(\mathrm{pH} 7 \cdot 0-8 \cdot 5)$, glycine- $\mathrm{NaOH}(\mathrm{pH}$ $8 \cdot 5-11 \cdot 0)$. Rates of G-3-P $\left(\mathrm{O}_{-}-0\right)$ and IDHAP $(\Delta---\Delta)$ formation in mitochondria ( $40 \mu \mathrm{g}$ protein) are shown. 


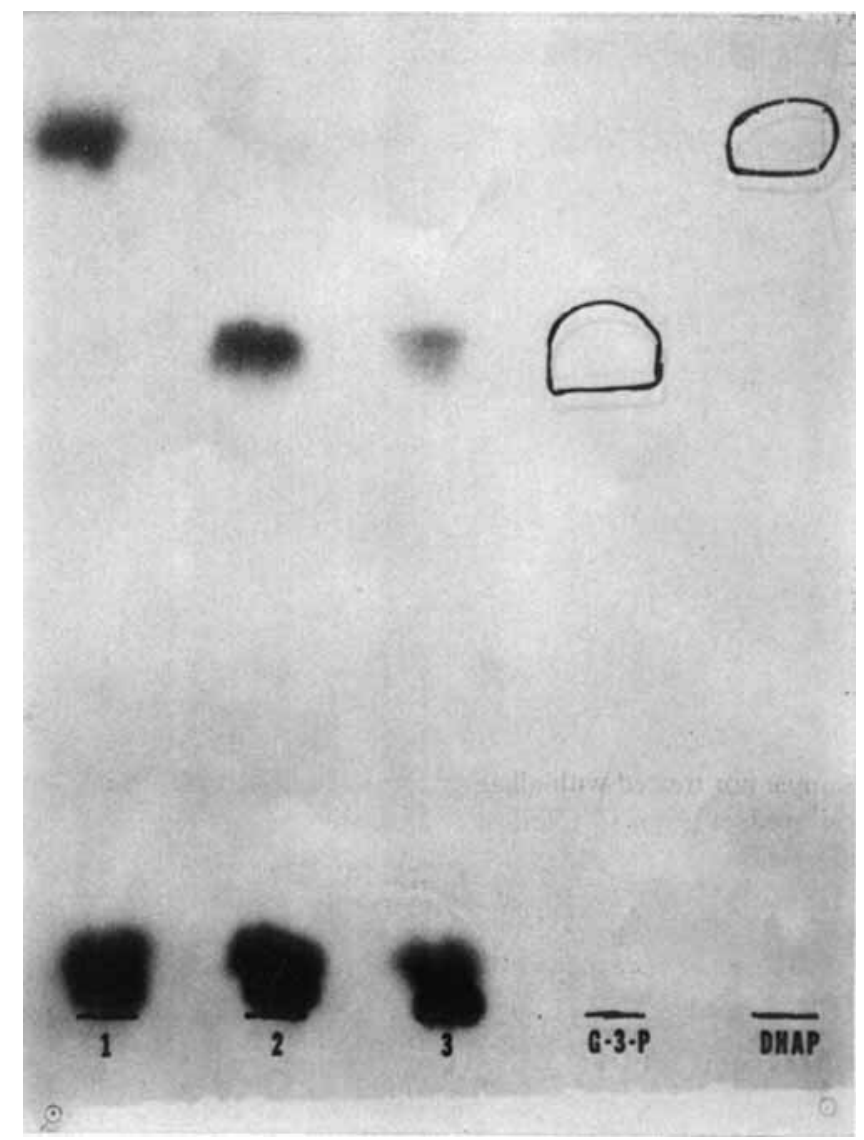

Fig. 1. Autoradiogram of the electrophoretogram showing labelled products formed enzymatically from radioactive glycerol or dihydroxyacetone. 1 . The incubation mixture contained citrate-phosphate buffer (60 mM, pH 6.1), ATP (5 mM), $\mathrm{MgCl}_{2}(5 \mathrm{~mm})$, mercaptoethanol ( $\left.5 \mathrm{~mm}\right)$, NaF (20 mM), 1-chloro, 3-hydroxyacetone phosphate $(25 \mu \mathrm{M})$, and $\left[\mathrm{U}^{14} \mathrm{C}\right]$ dihydroxyacetone $(0 \cdot 1 \mathrm{~mm}, 3.5 \times 105$ c.p.m.) in a total vol of $0.1 \mathrm{ml}$. The mixture was incubated at $37^{\circ} \mathrm{C}$ for $15 \mathrm{~min}$ and then $30 \mu \mathrm{l}$ of 0.3 $\mathrm{M}$-oxalic acid was added to stop the reaction as described in the text. An aliquot $(20 \mu 1)$ of the resulting mixture was spotted on Whatman No. 1 paper which was subjected to high voltage paper electrophoresis $(4000 \mathrm{~V}, 30 \mathrm{~min}$ at $\mathrm{pH} 1 \cdot 5)$ to separate the phosphorylated product(s) from labelled substrate. The radioactive spots were located by autoradiography as shown above. 


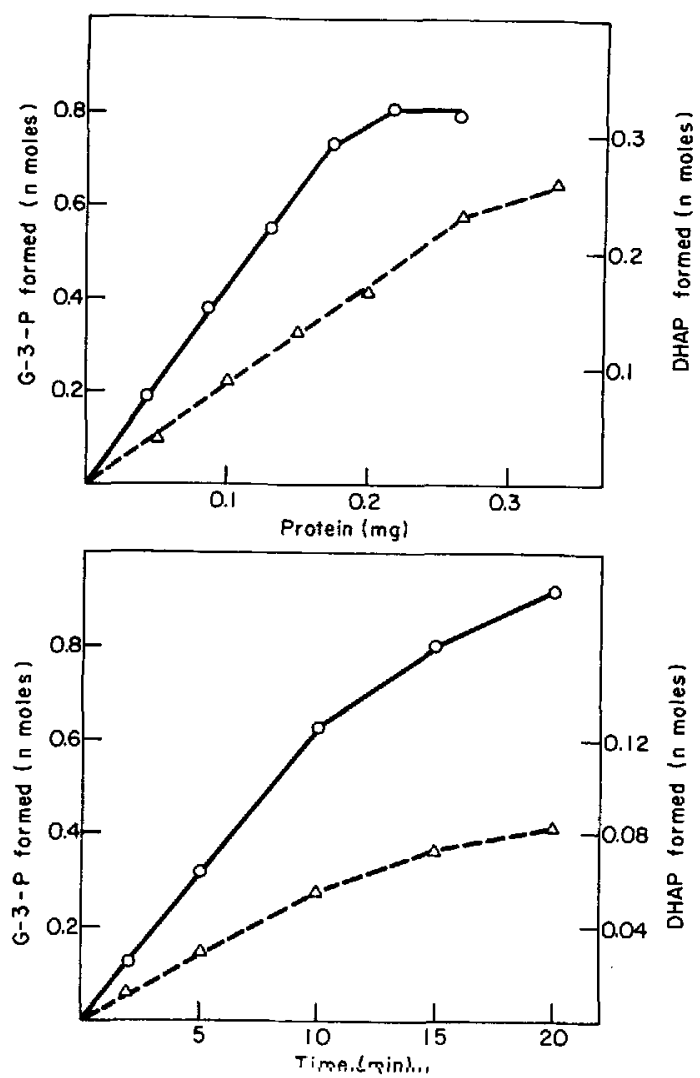

FIG. 3. Enzymatic phosphorylation of glycerol and dihydroxyacetone in mitochondria as a function of enzyme titer (upper) and time (lower). The conditions were the same as described in Table 1. A crude mitochondrial fraction containing synaptosome and myelin $(0.17 \mathrm{mg}$ protein for the lower figure) was used. A $10 \mathrm{~min}$ incubation time was used for the upper figure. The amount of G-3-P (O--O) and DHAP $(\triangle---\triangle)$ formed are shown.

$0.8 \mathrm{nmol} / \mathrm{min}$ per $\mathrm{mg}$ protein for the phosphorylation of glycerol. An attempt was made to determine the $K_{m}$ for ATP at fixed $\mathrm{Mg}^{2+}(0.01 \mathrm{M})$ and dihydroxyacetone $(0.2 \mathrm{~mm})$ or glyccrol $(0.2 \mathrm{~mm})$ concentrations. The data are somewhat more variable, probably because of the presence of ATPase activity in mitochondria. An approximate $K_{m}$ for ATP of $0.15 \mathrm{~mm}$ with glycerol and $3 \mathrm{mM}$ with dihydroxyacetone was obtained.

The above results were obtained when the enzymatic reactions were carried out at physiological $\mathrm{pH}$ (pH 7). When similar experiments were done at the $\mathrm{pH}$ optimum of the enzyme ( $\mathrm{pH} 10.0)$, the $K_{m}$ for glycerol was found to be $20 \mu \mathrm{M}$ and $2.45 \mathrm{nmol}$ of glycerol was phosphorylated/min per $\mathrm{mg}$ of the mitochondrial protein. The corresponding values for dihydroxyacetone were $0.2 \mathrm{~mm}\left(K_{m}\right)$ and $1.5 \mathrm{nmol} / \mathrm{min}$ per $\mathrm{mg}$ of protein at $\mathrm{pH} 10$.

\section{Properties of the cytosol enzyme}

The $\mathrm{pH}$ optimum of the enzyme from the $100,000 \mathrm{~g}$ supernatant was found to be quite different for dihydroxyacetone as compared to that of glycerol. Whereas the $\mathrm{pH}$ optimum for the formation of DHAP from
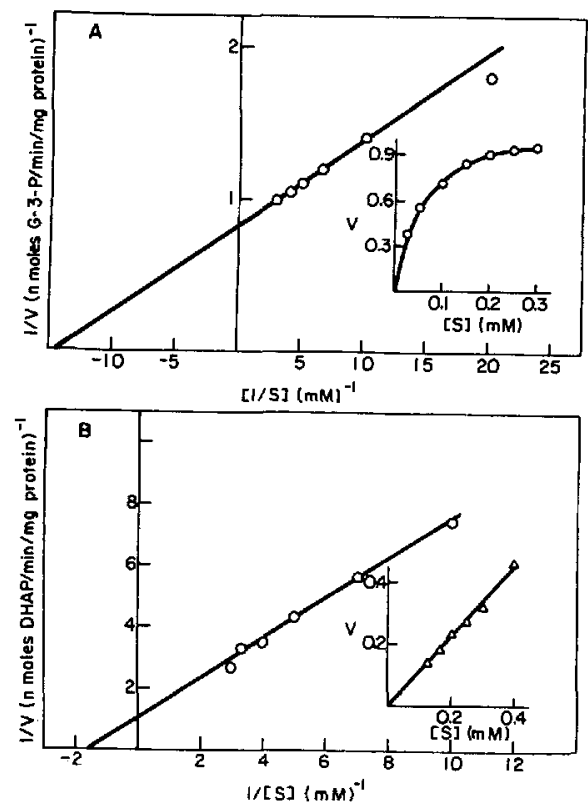

FIG. 4. Effect of increasing concentration of glycerol (A) and dihydroxyacetone (B) on the mitochondrial kinase activity. The reaction conditions were same as in Table 1 with the substrate concentration varying as indicated. The reaction time was $15 \mathrm{~min}$ and $0.17 \mathrm{mg}$ mitochondrial protein was used. The double reciprocal plot $(1 / s$ vs $1 / v)$ is shown in this figure with the effect of increasing substrate concentration ( $v$ vs $s$ ) in the insets.

dihydroxyacetone was 6.0 (Fig. 5), the $\mathrm{pH}$ optimum for glycerol was 10.4 (Fig. 5), the same as the mitochondrial enzyme. The activity towards glycerol phosphorylation was much less in this fraction than the dihydroxyacetone kinase activity. These and other properties indicate that more than one enzyme is involved in the phosphorylation of glycerol and dihydroxyacetone in the cytosol fraction. This was verified by the separation of dihydroxyacetone kinase activity from the glycerol kinase activity by ammonium sulphate fractionation of the $100,000 \mathrm{~g}$ supernatant (Table 3). By this method the dihydroxyacetone kinase activity could be completely separated from the glycerol kinase activity. Because of the low activity, no further study was made of glycerol kinase in the cytosol. The dihydroxyacetone kinase activity in the ammonium sulphate purified fraction $\left(S_{2}\right.$ fraction, Table 3) was studied in detail. The formation of DHAP from dihydroxyacetone and ATP was found to be linear with time and with the increasing amount of protein (Fig. 6). The effect of increasing the concentrations of dihydroxyacetone and ATP on the enzyme activity is shown in Fig. 7. The $K_{m}$ for dihydroxyacetone was found to be $60 \mu \mathrm{M}$, and a $V_{\max }$ of $1.0 \mathrm{nmol}$ of DHAP formed/min per $\mathrm{mg}$ of protein was obtained (Fig. 7A). At high magnesium concentration (10 mM) the $K_{m}$ for ATP was $0.7 \mathrm{mM}$ (Fig. 7B). The dihydroxyacetone phosphorylation, however, was inhibited by the high $\mathrm{Mg}^{2+}$ concentration. 
TABLE 3. FRACTIONATION OF GLYCEROL KINASE AND DIHYDROXYACETONE KINASE ACTIVTTY IN $100,000 g$ BRAIN SUPERNATANT BY AMMONIUM SULPHATE

\begin{tabular}{ccc}
\hline Fraction & $\begin{array}{c}\text { Glycerol kinase activity } \\
\text { nmol G-3-P/min per mg protein }\end{array}$ & $\begin{array}{c}\text { Dihydroxyacetone kinase activity } \\
\text { nmol DHAP/min per mg protein }\end{array}$ \\
\hline $100,000 \mathrm{~g}$ supernatant & $0 \cdot 109$ & 0.439 \\
$\mathrm{~S}_{1}$ & 0.083 & $0 \cdot 184$ \\
$\mathrm{~S}_{1}$ & 0.048 & 0.394 \\
$\mathrm{~S}_{2}$ & 0.000 & 0.770 \\
\hline
\end{tabular}

Dialyzed $100,000 \mathrm{~g}$ brain supernatant was fractionated with solid powdered ammonium sulfate as described in the text. The $S_{t}$ fraction contained all proteins which were precipitated when cytosol was $90 \%$ saturated with ammonium sulfate. the $S_{t}$ fraction was fractionated with ammonium sulphate to $S_{1}(0-50 \%$ saturated with ammonium sulphate) and $S_{2}(20-50 \%$ saturated with ammonium sulphate) as described in the text. The glycerol kinase and dihydroxyacetone kinase activities of various fractions are determined by the procedure as described in Tables 1 and 2.

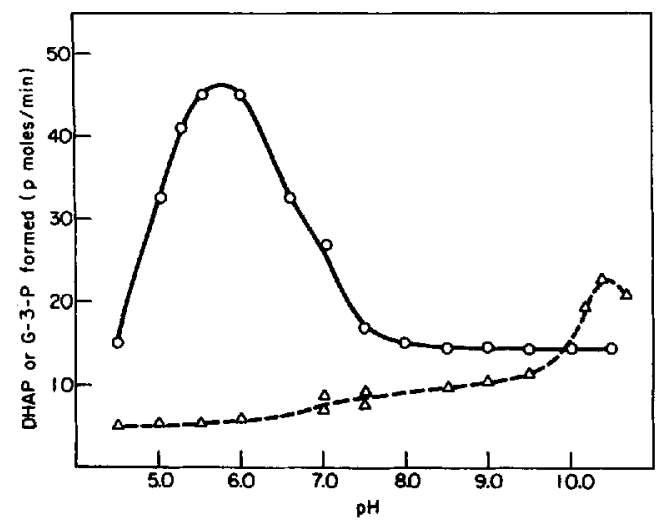

FIG. 5. The rate of phosphorylation of glycerol $(\triangle---\triangle)$ and dihydroxyacetone $(0-O)$ in the $100,000 \mathrm{~g}$ supernatant fraction as a function of $\mathrm{pH}$. The incubation mixtures were identical to those used for Fig. 2 except that brain $100,000 \mathrm{~g}$ supernatant $(0 \cdot 14 \mathrm{mg}$ protein) was used instead of the mitochondria protein. Citrate buffer was used for $\mathrm{pH}$ range $4 \cdot 5-5 \cdot 5$.

Effect of other analogs on the phosphorylation of dihydroxyacetone and glycerol

Glycerol kinase is known to phosphorylate dihydroxyacetone and L-glyceraldehyde (BUBLITZ \& KENNEDY, 1954; WIELAND \& SUYTER, 1957). Also the dihydroxyacetone kinase activity in the supernatant may be similar to the triokinase activity described in liver (Hers \& KusAKA, 1953). To establish the identity of these kinases the effects of D- and L-glyceraldehyde, D-fructose, D-fructose-6-phosphate, dihydroxyacetone and glycerol on the phosphorylation of labelled dihydroxyacetone and glycerol were studied. The assumption was that if these compounds were common substrates for the enzyme, they would inhibit the phosphorylation of the labelled substrates by the same enzyme. The effects of different compounds at low concentration are shown in Table 4. At low concentration dihydroxyacetone did not inhibit the mitochondrial glycerol kinase activity. Slight inhibition of the mitochondrial glycerokinase activity was seen with D- and L-glyceraldehyde. A similar result was found with the soluble glycerokinase activity (Table 4). The mitochondrial dihydroxyacetone kinase
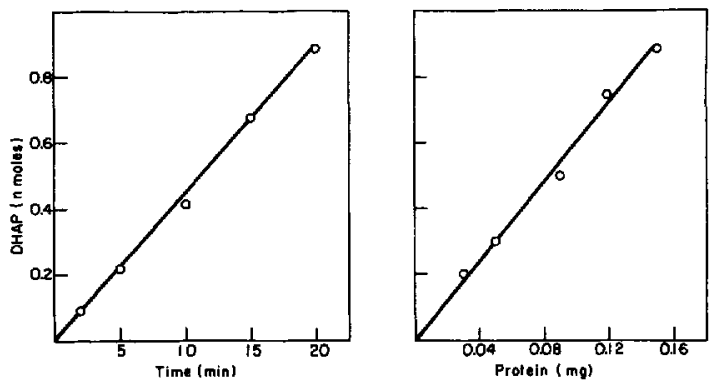

FIG. 6. Effect of increasing time and enzyme concentration on the phosphorylation of dihydroxyacetone by the $S_{2}$ supernatant fraction. The reaction mixture contained citrate phosphate buffer ( $60 \mathrm{~mm}, \mathrm{pH} 6 \cdot 1)$. ATP ( $5 \mathrm{mM}$ ), Mg $\mathrm{Cl}_{2}$ (5 mM), 2-mercaptoethanol (5 mM), NaF (20 mM), [U- ${ }^{14} \mathrm{C}$ ]dihydroxyacetone $(0-2 \mathrm{mM}, 60 \mu \mathrm{Ci} / \mu \mathrm{mol})$ and $\mathrm{S}_{2}$ fraction in a total vol of $0.1 \mathrm{ml}$. The assay condition was same as described in Table 1 . The reaction time was 10 $\min$ for the protein concentration study. The time course study was done with $0.12 \mathrm{mg}$ of $\mathrm{S}_{2}$ fraction protein.
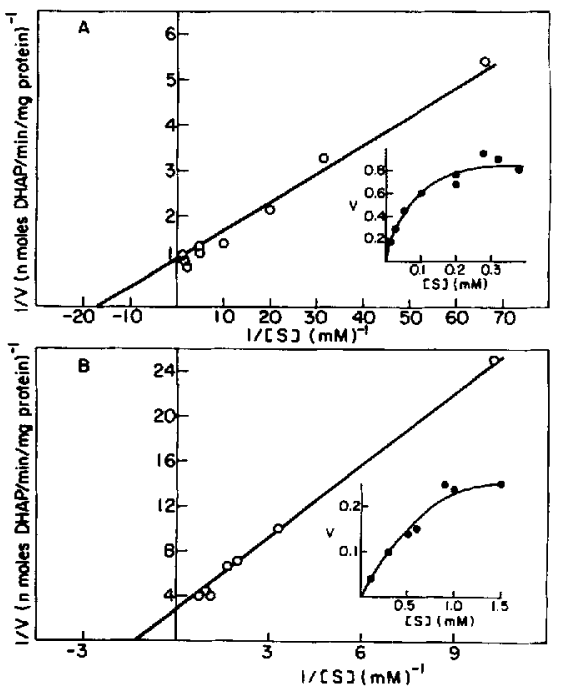

FIG. 7. Effect of changing the concentration of dihydroxyacetone (A) and ATP (B) on the phosphorylation of dihydroxyacetone by the supernatant $S_{2}$ fraction. The assay conditions were similar to those described under Fig. 6. The double reciprocal plot $(1 / s$ vs $1 / v)$ is shown in the figure, with the effect of increasing substrate concentration indicated in the insets. 
TABle 4. EfFect of Different COMPOUNDS ON THE ENZyMatic PHOSPHORYLATION OF GLYCEROL AND DIHYDROXYACETONE

\begin{tabular}{|c|c|c|c|c|}
\hline \multirow[b]{3}{*}{ Additions } & \multicolumn{4}{|c|}{ Relative enzyme activity and source } \\
\hline & \multicolumn{2}{|c|}{ Glycerol kinase } & \multicolumn{2}{|c|}{ Dihydroxyacetone kinase } \\
\hline & mitochondria & cytosol & mitochondria & cytosol \\
\hline None & 100 & 100 & 100 & 100 \\
\hline Dihydroxyacetone (0.9 mM) & 100 & 102 & - & - \\
\hline D-glyceraldehyde $(0.9 \mathrm{~mm})$ & 80 & 70 & 11 & 55 \\
\hline L-glyceraldehyde $(0.9 \mathrm{~mm})$ & 80 & 85 & 85 & 80 \\
\hline D-fructose $(0.2 \mathrm{~mm})$ & - & 100 & - & 95 \\
\hline D-fructose-6-P $(0.2 \mathrm{~mm})$ & - & - & - & 92 \\
\hline glycerol $(0.2 \mathrm{~mm})$ & - & -- & 96 & 120 \\
\hline
\end{tabular}

The conversions of $\left[1-{ }^{14} \mathrm{C}\right]$ glycerol and $\left[\mathrm{U}_{-}{ }^{14} \mathrm{C}\right]$ dihydroxyacetone to radioactive G-3-P and DHAP respectively were followed under conditions described in Tables 1 and 2 . The glycerol kinase and dihydroxyacetone kinase activities in the absence of any other substrate were arbitrarily set at 100 and the relative rates in the presence of other non-radioactive substrates are given below. The concentrations of the nonradioactive carbohydrates present in the incubation mixture are given above.

activity was strongly inhibited by glycerol and L-glyceraldehyde. On the other hand, no inhibition by glycerol of the soluble dihydroxyacetone kinase activity was seen. This soluble dihydroxyacetone kinase activity was inhibited by D-glyceraldehyde and to a slight extent by L-glyceraldehyde. D-fructose and $\mathrm{D}$ fructose-6-phosphate did not inhibit the dihydroxyacetone kinase activity.

Phosphorylation of different substrates by the supernatant enzyme with $\left[\gamma^{32} P\right] A T P$

The phosphorylation of glycerol, D- and L-glyceral-

TABLE 5. ENZYMATIC PHOSPHORYLATION OF DIFFERENT SUBSTRATES BY $\left[\gamma^{32} \mathrm{P}\right]$ ATP

\begin{tabular}{lcc}
\hline & Substrate & $\begin{array}{c}32 \text { P-labelled product } \\
\text { formed } \\
\text { pmol }\end{array}$ \\
\hline 1 & none & 45 \\
2 & dihydroxyacetone & 240 \\
3 & {$\left[\right.$ - $^{14}$ C]dihydroxyacetone } & $245(210)^{*}$ \\
4 & D-glyceraldehyde & 70 \\
5 & L-glyceraldehyde & 100 \\
6 & glycerol & 25 \\
7 & dihydroxyacetonet & 0 \\
8 & dihydroxyacetone & $255 \ddagger$ \\
\hline
\end{tabular}

The incubation mixture contained citrate-phosphate buffer $(60 \mathrm{~mm}, \mathrm{pH} 6 \cdot 1)$, 2-mercaptoethanol (5 mM), NaF (20 mM), $\quad \mathrm{MgCl}_{2} \quad(5 \mathrm{~mm}), \quad$ chlorohydroxyacetone-P (0.025 mM). $\left[\gamma^{32} \mathbf{P}\right]$ ATP $\left(0.2 \mathrm{~mm}, 1.2 \times 10^{5}\right.$ c.p.m. $\left./ \mathrm{nmol}\right)$ different substrates $(0.4 \mathrm{~mm})$ as indicated above and brain $\mathrm{S}_{2}$ fraction $(0.12 \mathrm{mg}$ protein) in a total vol of $0.1 \mathrm{ml}$. The mixtures were incubated at $37^{\circ} \mathrm{C}$ for $30 \mathrm{~min}$. The products formed were first reduced with $\mathrm{NaBH}_{4}$ and the excess $\left.{ }^{32} \mathrm{P}\right] A T P$ was hydrolyzed by $1 \mathrm{~N}-\mathrm{HCl}$ at $100^{\circ} \mathrm{C}$ as described in the text. The radioactive compounds were separated by high voltage paper electrophoresis and the radioactivity present in the G-3-P spot was determined.

* The figure in the parentheses shows the amount of ${ }^{14} \mathrm{C}$-labelled product formed.

† The enzyme was heated at $100^{\circ} \mathrm{C}$ for $10 \mathrm{~min}$ before use.

\pm In this tube the $\left[{ }^{32} \mathrm{P}\right]$ DHAP formed was directly measured without reduction and acid hydrolysis. dehyde and dihydroxyacetone was studied by using labelled ATP and the $\mathrm{S}_{2}$ fraction of the cytosol (Table 5). As mentioned before, the acid labile products were first reduced with $\mathrm{NaBH}_{4}$ to acid-stable G-3-P, and the excess $\left[\gamma^{32} \mathrm{P}\right]$ ATP was hydrolyzed to ${ }^{32} \mathrm{P}_{i}$ by acid hydrolysis before separation by electrophoresis. The resulting ${ }^{32} \mathbf{P}_{i}$ was well separated from G-3-P. Using this assay system it was seen that dihydroxyacetone was the best substrate for the enzyme (Table 5). This was verified also by using ${ }^{14} \mathrm{C}$-labelled dihydroxyacetone and by measuring DHAP without reduction and acid hydrolysis (Table 5). The enzyme fraction phosphorylated D-glyceraldehyde and L-glyceraldehyde. As shown before with labelled glycerol, glycerol was not phosphorylated in this system.

\section{Change in brain glycerol kinase and dihydroxyacetone} kinase activity with age

During myelination there is an accelerated rate of lipid synthesis in the brain (WeLLS \& DiTtMer, 1967). To check whether there is any change in the activity of these kinases during myelination, the specific activities of glycerol kinase and dihydroxyacetone kinase in the mitochondrial and the cytosol fractions in rat brains before myelination (7-day old rats), during active myelination (15-day old rats) and after myelination (2 months and 1-year old rats) were measured. In the $100,000 \mathrm{~g}$ supernatant fraction of brain there appears to be a slight increase $(10-15 \%)$ in specific activity for both glycerol and dihydroxyacetone phosphorylation in the 15-day old rats, compared to that of 7-day old rats. However, the activity is not significantly different from that of adult rats. Activity for glycerol phosphorylation in the mitochondrial fraction appears to be highest at 7 days and decreases slightly thereafter.

\section{DISCUSSION}

A direct optical assay for the glycerol kinase and dihydroxyacetone kinase activities based on the oxidation or reduction of pyridine nucleotides was not 
possible due to the low activity of these enzymes in brain. Consequently, a radioassay was employed which yielded the desired sensitivity. An alternative method for the separation of glycerol from G-3-P by adsorption to discs of DEAE-cellulose paper has been used for a sensitive radioassay (NEwsHolme et al, 1967). It was found that the glycerokinase activity in brain could be measured accurately by this method. However, the dihydroxyacetone kinase activity could not be measured reliably in this way because a large fraction of labelled dihydroxyacetone was also adsorbed on the DEAE-filter paper discs. The electrophoretic method used here was found to be accurate, reliable, and also useful in separating G-3-P from DHAP. Using this assay, brain glycerokinase activity was found primarily in the mitochondrial fraction. This enzyme escaped detection in brain (WIELAND \& SuYter, 1957; VerNon \& WALKer, 1970) in the past probably due to its low activity and its association with brain mitochondria. Though in most tissues this enzyme is present in the cytosol fraction, in insect flight muscle and bull spermatozoa glycerol kinase has been described to be primarily present in mitochondria (Newsholme \& TAYlor, 1969; MoHRI \& MASAKI, 1967). A similar enzyme, hexokinase, which is present in the cytosol in most organs, has been shown to be associated primarily with brain mitochondria (CRANE, 1962). The properties of the brain glycerokinase are similar to those of glycerol kinase found in other organs (THORNER \& PAULus, 1973). The brain enzyme, like other glycerol kinases, has a high $\mathrm{pH}$ optimum and is stimulated by thiols. This enzyme also phosphorylates dihydroxyacetone and possibly L-glyceraldehyde. However, like the liver enzyme (Thorner \& Paulus, 1973), the $K_{m}$ for glycerol phosphorylation by the brain enzyme is much lower than the $K_{m}$ for dihydroxyacetone phosphorylation (70 $\mu \mathrm{M}$ vs $0.6 \mathrm{~mm}$ ). This difference in $K_{m}$ probably explains the fact that at low concentration glycerol inhibits the dihydroxyacetone phosphorylation in mitochondria, while the converse is not true (Table 4). L- and D-glyceraldehyde partially inhibit the phosphorylation of glycerol (Table 4). L-glyceraldehyde inhibits glycerol phosphorylation by being a substrate for the enzyme. HAYASHI \& LIN (1967) showed that D-glyceraldehyde also acts as a substrate for glycerokinase. However, the product is an unstable hemiacetal phosphate which is hydrolyzed by water to $\mathbf{P}_{i}$. Thus D-glyceraldehyde would inhibit the phosphorylation of glycerol by competing for the enzyme, and also by stimulating the hydrolysis of ATP in the reaction mixture.

As mentioned before, the $K_{m}$ for ATP could not be accurately determined with the crude mitochondrial enzyme and the values obtained are probably higher than the real $K_{m}$. Actually, the substrate for the kinase is not free ATP but the (Mg-ATP) ${ }^{2-}$ complex (Thorner \& Paulus, 1973). However, because the $\mathrm{Mg}^{2+}$ concentration (10 mM) was much higher than the $\mathrm{ATP}^{4-}$ concentration (0.1-5 mM) and the formation constant of the (Mg-ATP) ${ }^{2-}$ complex is high $\left(5.8 \times 10^{4}\right.$, see Burton, 1959), the ATP in the reaction mixture was mainly present as the $(\mathrm{Mg}-\mathrm{ATP})^{2--}$ complex.

The properties of the dihydroxyacetone kinase activity in the cytoplasm are quite different than those of the glycerol kinase. The pH optima differ greatly (6.0 for dihydroxyacetone kinase vs 10.5 for glycerol kinase) and the $K_{m}$ for dihydroxyacetone is much lower for this enzyme than it is with the mitochondrial enzyme. The partially purified enzyme did not have any glycerol kinase activity, and glycerol at high concentration did not compete for the phosphorylation of dihydroxyacetone with this enzyme. These results suggest that the soluble dihydroxyacetone kinase is an enzyme distinct from the glycerol kinase. This enzyme is probably similar to the triokinase of liver. Triokinase has been shown to phosphorylate dihydroxyacetone and D-glyceraldehyde, but not glycerol or L-glyceraldehyde (HERS, 1962). D-glyceraldehyde inhibits the phosphorylation of dihydroxyacetone by this enzyme and is also phosphorylated to D-glyceraldehyde-3-phosphate. However, D-glyceraldehyde kinase activity is much lower than the dihydroxyacetone kinase activity, and L-glyceraldehyde is also phosphorylated by this enzyme fraction. It is possible that some other enzyme is present in this fraction which phosphorylates L-glyceraldehyde. Because the enzyme is fairly crude and has a very low specific activity, nothing definite can be established about the substrate specificity until the enzyme is further purified. Recently, triokinase activity has been demonstrated in erythrocytes (BEUTLER \& GUINTO, 1973). The specific activity of the erythrocyte enzyme is somewhat lower than the brain enzyme; and the kinetic properties of the erythrocyte enzyme are different than the enzyme described here.

The metabolic role of these enzymes is not very clear. Glycerol kinase is believed to be important for the reutilization of free glycerol formed by lipolysis in tissues. The free glycerol concentration in brain is reported to be 0.4-0.7 mm (WIELANI), 1957). Because the $K_{m}$ of the brain mitochondrial glycerokinase is low $(70 \mu \mathrm{M})$, the brain would be able to utilize the endogenous glycerol very effectively. Glycerol may also diffuse from blood $(0.1-0.2 \mathrm{~mm}$-glycerol) to brain and would be utilized in that tissue. However, CRONE (1965) showed that glycerol is not easily transported across the blood-brain barrier. In such a case, glycerol kinase may be important only for the reutilization of free glycerol which is formed by the breakdown of glycerolipid in the brain. Similarly, dihydroxyacetone kinase may be important for the reutilization of dihydroxyacetone or D-glyceraldehyde in the brain. Dihydroxyacetone may be formed by the enzymatic oxidation of glycerol (glycerol dehydrogenase EC 1.1.1.6) or by the dephosphorylation of DHAP.

One important consequence of the presence of these enzymes in the brain is that in vivo conversion of labelled glycerol and dihydroxyacetone to different 
glycerolipids can be easily studied. As reported by different workers (LAPETINA et al., 1969; BENJAMINS \& MCKhanN, 1973; O'Brien \& Geison, 1974), we also found that $\left[{ }^{3} \mathrm{H}\right]$ - or $\left[{ }^{14} \mathrm{C}\right]$ glycerol, when injected intracranially is rapidly incorporated into brain lipid. We also found that $\left[{ }^{14} \mathrm{C}\right]$ dihydroxyacetone is incorporated into brain glycerolipid when administered by the same route. A detailed study of the conversion of these precursors into brain lipid might be useful to determine the importance of different pathways (glycerol-3-phosphate and acyl dihydroxyacetone phosphate pathways) in the brain for the biosynthesis of glycerolipid.

Acknowledgements - We gratefully acknowledge the technical assistance of Ms. CARYL BuRKe. This work was supported by Grant NS 08841 from the National Institute of Health.

\section{REFERENCES}

Benjamins J. A. \& McKhann G. M. (1973) J. Neurochem. 20, $1111-1120$

Beutler E. \& Guinto E. (1973) Blood 41, 559-568.

Brody T. M. \& Bain J. A. (1952) J. biol. Chem. 195, 685-696.

Bublitz C. \& Kennedy E. P. (1954) J. biol. Chem. 211. 951-961.

Burton K. (1959) Biochem. J. 71. 388-395.

Crane R. K. (1962) in The Enzymes (Boyer P. D., Lardy H. \& MYrBACK K., eds.) Vol. 6, pp. 47-66. Academic Press, New York.

Crone C. (1965) Acta. physiol. scand. 64, 407-417.

GlynN I. M. \& Chappell J. B. (1964) Biochem. J. 90, $147-149$

Gray E. G. \& Whittaker V. P. (1962) J. Anat. 96, 79-88.

Haessler H. A. \& Isselbacher K. J. (1963) Biochim. biophys. Acta 73, 427-436.

Hajra A. K. \& Agranoff B. W. (1968) J. biol. Chem. 243, $1617-1622$.
HARTMAN F. C. (1970) Biochemistry 9. 1776-1782.

HaYASHI S. \& LIN E. C. C. (1967) J. biol. Chem. 242, 1030-1035.

Hers H. G. (1962) in Methods in Enzymology (COLowick S. P. \& Kaplan N. O., eds.) Vol. V, pp. 362-364. Academic Press, New York.

Hers H. G. \& Kusaka T. (1953) Biochim. biophys. Acta $11,427-437$.

НокाN L. E. \& Hokin M. R. (1958) J. biol. Chem. 233 , 818-821.

Kalckar H. (1939) Biochem. J. 33. 631-641.

KenNedy E. P. (1962) Harvey Lect. 57, 143-171.

LABelle E. F. JR. \& HaJra A. K. (1972a) J. biol. Chem. 247. 5825-5834.

LaBelle E. F. JR. \& HaJra A. K. (1972b) J. biol. Chem. 247, 5835-5841.

Lapetina E. G., Rodriguez de Lores Arnaiz G. \& de Robertis E. (1969) Biochim. biophys, Acta 176, 643-646.

Lowry O. H., Rosebrough N. J., FarR A. L. \& Randall R. J. (1951) J. biol. Chem. 193, 265-275.

Meyerhof O. \& Lohmann K. (1934) Biochem. Z. 271, 89-110.

Mohri H. \& MaSAKı J. (1967) J. Reprod. Fert. 14. 179-194.

Newsholme E. A., Robinson J. \& TAylor K. (1967) Biochem J. 132. 338-346.

Newsholme E. A. \& TAYLOR K. (1969) Biochem. J. 112 , 465-474.

O'Brien J. F. \& Geison R. L. (1974) J. Lipid Re's. 15. 44-49.

Robinson J. \& Newsholme E. A. (1969) Biochem. $J .112$. $449-453$.

SChaCht J. \& AgRanoff B. W. (1972) J. biol. Chem. 247. $771-777$.

Thorner J. W. \& Paulus H. (1973) in The Enzymes (BOYER P. D., ed.) 3rd ed., Vol. VIII, pp. 487-508. Academic Press, New York.

VERNON R. G. \& WaLker D. G. (1970) Biochem. J. 119. 531-536.

WELLS M. A. \& DITTMER J. C. (1967) Biochemistry 6, 3169-3175.

WiEland O. (1957) Biochem. Z. 329. 313-319.

Wieland O. \& SuYter M. (1957) Biochem. Z. 329. 320-331. 